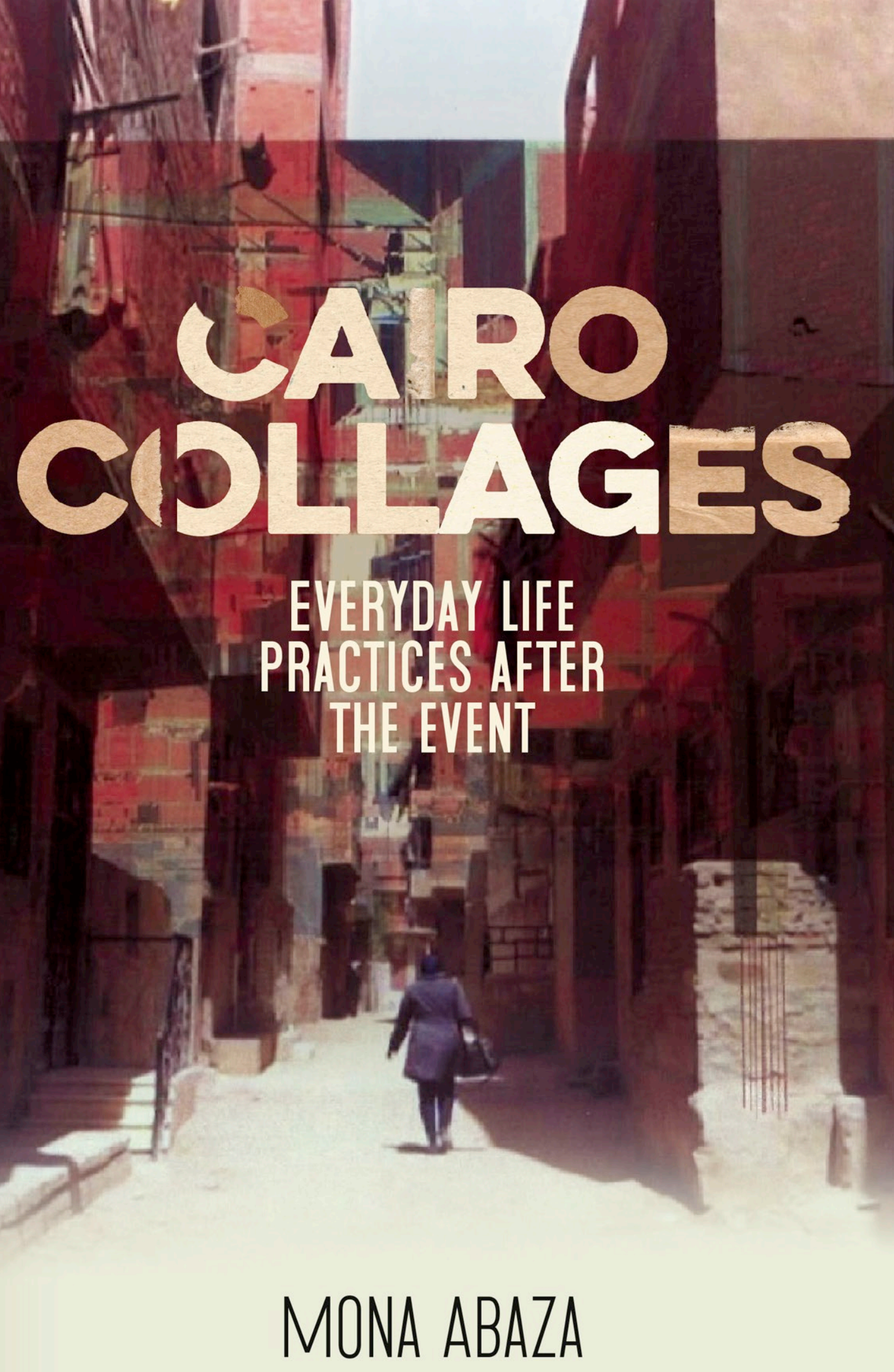




\section{Cairo collages}

\section{MANCHESTER

$$
1824
$$

Manchester University Press 
Mona Abaza - 9781526145123

Downloaded from manchesterhive.com at 04/26/2023 01:58:51PM via free access 


\title{
Cairo collages
}

Everyday life practices after the event

\author{
Mona Abaza
}

Manchester University Press 


\section{Copyright (C) Mona Abaza 2020}

The right of Mona Abaza to be identified as the author of this work has been asserted by her in accordance with the Copyright, Designs and Patents Act 1988.

Published by Manchester University Press

Altrincham Street, Manchester M1 7JA

www.manchesteruniversitypress.co.uk

British Library Cataloguing-in-Publication Data

A catalogue record for this book is available from the British Library

ISBN 9781526145116 hardback

First published 2020

The publisher has no responsibility for the persistence or accuracy of URLs for any external or third-party internet websites referred to in this book, and does not guarantee that any content on such websites is, or will remain, accurate or appropriate.

Cover image: Between walls by Laura Strauth

Cover design: riverdesignbooks.com

Typeset

by Toppan Best-set Premedia Limited 